\title{
Comparison of Rosin and Propolis Antimicrobials in Cellulose Acetate Fibers Against Staphylococcus aureus
}

\author{
Mikko Kanerva, ${ }^{\mathrm{a}, *}$ Vsevolod Matrenichev, ${ }^{\mathrm{b}}$ Rama Layek, ${ }^{\mathrm{a}}$ Timo M. Takala, ${ }^{\mathrm{c}}$ \\ Pekka Laurikainen, ${ }^{\mathrm{a}}$ Essi Sarlin, ${ }^{\mathrm{a}}$ Anna Maria Elert, ${ }^{\mathrm{d}}$ Vladimir Yudin, ${ }^{\mathrm{b}}$ Jani Seitsonen, ${ }^{\mathrm{e}}$ \\ Janne Ruokolainen, ${ }^{\mathrm{e}}$ and Per Saris ${ }^{\mathrm{c}}$
}

\begin{abstract}
The quantitative difference in the antibacterial response was measured for pine rosin and propolis against Staphylococcus aureus ATCC 12598. The activity was studied for fibrous networks that form entirely bio-based cellulose-acetate (CA) materials. The analysis considers the effects of bacterial input, additive dosage, solvent type, variation in preparation, as well as the effect of storage time. Based on the results, the electrospun network structure is dependent on the solvent and the concentration of rosin and propolis. Both rosin and propolis improved the cellulose acetate solution processability, yet they formed beads at high concentrations. Rosin and propolis created strong antibacterial properties when these material systems were immersed in the liquid for $24 \mathrm{~h}$ at room temperature. The response remained visible for a minimum of two months. The electrospun networks of water and DMAc solvent systems with 1 to 5 $w t \%$ rosin content were clearly more efficient (i.e., decrease of 4 to 6 logs in colony forming units per $\mathrm{mL}$ ) than the propolis networks, even after two months. This efficiency is likely due to the high content of abietic acids present in the rosin, which is based on the Fourier transform infrared spectra. The results of the additional analysis and cell cultivation with dermal fibroblast cells indicated an impairing effect on skin tissue by the rosin at a $1 \mathrm{wt} \%$ concentration compared to the pure CA fibers.
\end{abstract}

Keywords: Rosin; Propolis; Antibacterial; Cellulose acetate; Electrospinning

Contact information: a: Tampere University, Faculty of Engineering and Natural Sciences, PO Box 589, FI-33014 Tampere University, Finland; b: Institute of Macromolecular Compounds (IMC), Russian Academy of Sciences 31 Bolshoy pr. VO, Saint-Petersburg, 199004 Russia; c: Helsinki University, Department of Microbiology, PO Box 56, FI-00014 Helsinki, Finland; d: Bundesanstalt für Materialforschung und -prüfung (BAM), 12205 Berlin, Germany; e: Aalto University, School of Natural Sciences, Department of Physics, PO Box 14300, FI-00076 Aalto, Finland; *Corresponding author: mikko.kanerva@tuni.fi

\section{INTRODUCTION}

Natural additives in nano scale structures can result in synergetic features due to their complex development and effects of small size. Wood rosin is a substance that has been suggested to replace petroleum-based resins and polymerizing elements in structural polymers (Barrueso-Martínez et al. 2003; Liu et al. 2014). In addition, rosin has been used as an additive in food packaging materials due to its strong antimicrobial response (Niu et al. 2018). Rosin has also been used as an antibacterial agent in medical wound dressings (Sipponen et al. 2007). Rosin is mostly an amorphous compound that consists of a mixture of lipophilic components and phenol extracts. It can be found in tree sapwood and heartwood with different compositions (Sjöström 1993; Vainio-Kaila et al. 2017b). The 
interaction between various bacterial strains and rosin's pimaric, labdane, and abietic acids is not fully clear. However, the antibacterial activity is associated with the malfunction of the cell wall energy synthesis after contact with rosin's acids (Söderberg et al. 1990; Sipponen et al. 2009). The antibacterial activity in pure rosin has been clearly reported against Gram-positive Staphylococcus aureus and Streptococcus pneumonia strains. Additionally, it has been reported against Gram-negative Escherichia coli and Salmonella enterica strains (Söderberg et al. 1990; Vainio-Kaila et al. 2017a). The low molecular weight solvent components are usually removed to achieve a definite chemical composition (Nirmala et al. 2013).

Propolis is a complex, wax-like organic product that combines the best characteristics of plant and animal-based production in nature. The pharmacological features of propolis have been realized for centuries. Barbosa et al. (2015) extracted hydroalcoholic antioxidants from red propolis to balance the inflammatory response of artificial nerve conduits. Similarly, Awale et al. (2008) reported cytotoxic activity of propolis against tumor cells. Additionally, propolis can be used to form high quality electrospun nanofibers when blended with synthetic polymers such as polyurethane, polylactic acid, and polyvinylpyrrolidone to gain observable antibacterial activity (Kim et al. 2014; Sutjarittangtham et al. 2014; Asawahame et al. 2015). Propolis (sometimes called bee glue) is formulated by honeybees to fill small crevices and pin holes in the walls of the wooden environment around their nest (Savolainen 2016). Likewise, bees use propolis to embalm intruders too large to be removed from the nest. Bees digest rosin and wax-like fluids from buds of different trees and plants to prepare propolis. The main components of propolis are various flavonoids, phenolics, organic acids, alcohols, and pollen (Toreti et al. 2013). The exact chemical content of pollen depends on the environment and plants available to the bees (Fatrcova-Šramková et al. 2013).

These natural substances (rosin and propolis) are superior to most of the synthetic biocides because they are antimicrobial, and they support biodegradation or the healthy cell development in various host organisms. The carrier structure for making rosin- or propolis-containing biopolymer films and fibers could be made of cellulose acetate (CA). CA has high throughput and thermal stability when it is electrospun into high surface area to volume networks (Luo et al. 2013). Furthermore, deacetylation of CA can be used to transform CA based fibrous networks into pure cellulose type systems (Son et al. 2004). In recent studies, CA fibers and films with antibacterial activity have been prepared primarily using silver and $\mathrm{ZnO}$ nanoparticles (Son et al. 2006; Anitha et al. 2012). Moreover, CA films and electrospun networks have been applied to vitamin, enzyme, and drug immobilization products instead of tissue engineering products (Konwarh et al. 2013). Rosin and propolis can be used in synthetic polymers, but their comparative effects have not been surveyed especially when forming biobased material systems.

In this work, the antibacterial response of rosin and propolis were quantitatively compared. The effects of both natural substances were studied in fibrous networks to create entirely biobased CA materials. The fibrous networks were analyzed in terms of their antibacterial behavior against the Gram-positive S. aureus ATCC 12598 in the Ringer's medium. The purpose of this study was to analyze the antibacterial activity of rosin and propolis in the CA materials while considering the effects of bacterial input, additive concentration, solvent type, variation in preparation, as well as the effect of storage time. Additionally, the effects of rosin integration on the biocompatibility, in terms of the viability of dermal fibroblast cells, was studied. 


\section{EXPERIMENTAL}

\section{Polymers and Natural Additives}

The cellulose acetate (CA) was purchased from Merck (Steinheim, Germany) $\operatorname{KGaA}\left(M_{\mathrm{w}}=30,000\right.$ and acetyl content of $\left.39.8 \mathrm{wt} \%\right)$. The dimethylacetamide (DMAc) was provided by Sigma Aldrich (Steinheim, Germany).

The rosin was a commercial, industrial grade extract that was provided by Forchem (Rauma, Finland). The rosin had been derived from pine (gum) rosin and was received in a crushed particle form (batch 16032017, acid value $167 \mathrm{mg} \mathrm{KOH} / \mathrm{g}$, softening point $\left.74{ }^{\circ} \mathrm{C}\right)$.

Two different propolis products were selected for the study: nutritive capsules (Gélules Ultra, Apimab Laboratoires, Clermont-l'Hérault, France) in powder form (encapsulated) and hand collected raw propolis (Rudenko, batch 0464316, St. Petersburg, Russia) in its original form collected during the summer of 2017 (half a year prior to the fiber preparation). In this study, the Gélules Ultra is referred to as 'propolis I' and the Rudenko as 'propolis II'. The two selected propolis products represented the different processing levels of propolis.

\section{Electrospinning and Film Preparation}

The cellulose acetate (CA) was dissolved in two different kinds of solvent systems: water and acetone, and DMAc and acetone. In these systems, the CA concentration ranged between a 5 and $20 \mathrm{wt} \%$ content. The percentage of water in the $\mathrm{H}_{2} \mathrm{O}$ systems was $15 \mathrm{wt} \%$, and the DMAc percentage in the DMAc systems was $33 \mathrm{wt} \%$. For preparing solutions for electrospinning, the required amount (1 to $5 \mathrm{wt} \%$ ) of rosin or propolis was added to the CA solutions. The CA-rosin/propolis solutions were stirred at room temperature until dissolution of the rosin or propolis. Finally, the systems were sonicated for $5 \mathrm{~min}$.

The electrospinning device included a high voltage generator (Chargemaster, SIMCO, Santa Clara, CA, USA), a syringe, a needle, a syringe pump, and a ground electrode. The needle was connected to the high voltage supply, which can generate direct current voltages up to $50 \mathrm{kV}$. The distance between the needle tip and the ground electrode ranged between 15 and $30 \mathrm{~cm}$. Positive voltage applied to polymer solutions ranged between 10 and $16 \mathrm{kV}$. CA solutions were delivered via a syringe pump to control the mass flow rate.

The mass flow rate values ranged between 5 and $20 \mathrm{~mL}$ per $\mathrm{h}$. The electrospinning was performed at room temperature. For the study of the preparation effects (batch dependency), a parallel series of fibers were prepared at IMC (Russia) using a Nanon-01 A (MECC Co., Minneapolis, US) with the same control parameters used earlier. Additionally, the polymer films were produced by a tape casting method with the following three compositions $\left(\mathrm{H}_{2} \mathrm{O}\right.$ systems): $\mathrm{CA}(10 \mathrm{wt} \%)$ as the reference, $\mathrm{CA}(10 \mathrm{wt} \%)$ plus rosin (5 $\mathrm{wt} \%)$, and CA (10 wt $\%)$ plus rosin (1 wt $\%)$.

\section{Characterization}

Fourier transform infrared spectroscopy (FTIR) spectra of the rosin and propolis, the prepared nanofibers, and the film samples were obtained with a Tensor 27 spectrophotometer (Bruker, Billerica, US) to characterize the content of the materials. The viscosity of the solutions for electrospinning was determined with an Anton Paar viscometer (model Physica MCR 301, Graz, Austria) at $25^{\circ} \mathrm{C}$. Visual light microscopy 
(DM 2500 M, Leica, Wetzlar, Germany) and scanning electron microscopy (SEM) using a field emission gun electron microscope (ULTRAplus, Zeiss, Oberkochen, Germany) were used for studying the fiber networks and polished laminate cross sections. The morphology and fiber diameters were estimated by analyzing the SEM images.

AFM studies were obtained using a NanoIR2S (Bruker/Anasys Instruments, Santa Barbara, CA, USA) coupled with a multichip QCL source (MIRcat, Daylight Solutions, San Diego, CA, USA). An Au coated silicon probe (contact AFM-IR, cantilever, Anasys Instruments, Santa Barbara, US) was employed. Electrospun network samples for AFM were first embedded in epoxy by casting (Epofix, Struers, Cleveland, US). After the embedment, 100 to $150 \mathrm{~nm}$ thick slices were cut of the fiber network's cross section by using a cryo-ultramicrotome (Leica Ultracut 7, Wetzlar, Germany). The slices were captured on copper grids covered by a carbon film (Electron Microscopy Sciences, Hatfield, US). The grids with the samples were mounted on metallic chips (Ted Pella, Redding, CA, USA) for AFM.

\section{Antibacterial Activity}

Antimicrobial activities of the electrospun networks were tested against the indicator bacteria Staphylococcus aureus ATCC 12598. The indicator was cultured at $37{ }^{\circ} \mathrm{C}$ in lysogeny broth (LB) with $1.5 \%$ agar for solid media. Antibacterial tests with the electrospun material were carried out in a Ringer's solution of $1 / 4$ strength $(2.25 \mathrm{~g} \mathrm{NaCl}$, $0.105 \mathrm{~g} \mathrm{KCl} 0.06 \mathrm{~g} \mathrm{CaC}_{12}$, and $0.05 \mathrm{~g} \mathrm{NaHCO}_{3}$ in $1 \mathrm{~L}$ of distilled water, Merck). The sample material (approximately $2.5 \mathrm{mg}$ ) was collected from approximately 1 by $1 \mathrm{~cm}$ samples of electrospun networks (on aluminum backing during spinning).

The indicator strain was first cultured overnight in the LB broth. The number of colony-forming units per $\mathrm{mL}$ of the $\mathrm{o} / \mathrm{n}$ culture was determined by serial dilutions and plating onto the LB agar. From the serial dilutions of $10^{-3}$ to $10^{-4}, 1 \mathrm{~mL}$ (referring to about $10^{5}$ to $10^{7} \mathrm{cfu}$ per $\mathrm{mL}$ ) was used for the antimicrobial test by mixing with the sample material (approximately $1 \mathrm{~cm}^{2}$ of network) in $2 \mathrm{~mL}$ Eppendorf tubes. The mixtures were incubated for $24 \mathrm{~h}$ at room temperature in a rotator $(22 \mathrm{rpm})$. After incubation, the samples were serially diluted in 1/4 strength Ringer's solution and plated onto the LB agar. This was performed to determine the bacterial survival by colony counting. At a minimum, two separate analysis campaigns per sample series were done, and the average was calculated for indicating the survival in the graphs.

\section{Cultivation of Dermal Fibroblast Cells}

The biological material of the skin biopsy of a young, healthy donor was used to extract the dermal fibroblasts of the skin. To extract the initial culture of dermal skin fibroblasts, a standard enzymatic procedure was used (Varga et al. 2005). The cell suspension obtained during the enzymatic treatment was cultured in a DMEM nutrient medium (PanEco, Berg am Irchel, Switzerland) with an additive of L-glutamine, 10\% bovine fetal serum, and penicillin (100 units per $\mathrm{mL})$ and streptomycin $(100 \mu \mathrm{g}$ per $\mathrm{mL})$ (all reagents by Gibco, Waltham, MA, USA). Cultivation took place in a $\mathrm{CO}_{2}$ incubator (3423, Thermo Fisher Scientific, Waltham, MA, USA) at a temperature of $37^{\circ} \mathrm{C}$ and a high humidity. The concentration of $\mathrm{CO}_{2}$ was $5 \%$. In total, 3 to 12 passages were used for the experiment. The colorimetric assay (MTT) for the number of viable cells was carried in phases as described in Table 1. 
Table 1. The Preparation and Analysis Steps of the MTT Assay for CA Films

\begin{tabular}{|c|c|}
\hline Step & Description \\
\hline 1 & $\begin{array}{c}\text { The experimental samples of CA films were disinfected, cut into pieces by the } \\
\text { size of a 24-well culture plate, and placed in wells. }\end{array}$ \\
\hline 2 & $\begin{array}{c}\text { A cell suspension in the culture medium containing 25,000 cells was added to } \\
\text { the wells. }\end{array}$ \\
\hline 3 & $\begin{array}{c}\text { The cells were incubated for 1 and 4 days. } \\
\text { yl)-2,5-diphenyltetrazolium bromide) and the cells were incubated for two more } \\
\text { hours. }\end{array}$ \\
\hline 5 & $\begin{array}{c}\text { After removing the solution, the formed formazan crystals were extracted by } \\
\text { adding dimethyl sulfoxide to the wells. }\end{array}$ \\
\hline 6 & After mixing, the solution was placed into 96-well culture plates. \\
\hline 7 & $\begin{array}{c}\text { The optical density of the solution was measured at a wavelength of } 570 \mathrm{~nm} \\
\text { using a Nano spectrophotometer (SPECTROstar, BMG, Ortenberg, Germany). } \\
\text { The optical density correlated with the number of viable cells. }\end{array}$ \\
\hline
\end{tabular}

\section{RESULTS AND DISCUSSION}

\section{Spinnability and Fiber Size}

The spinnability of the rosin and propolis containing CA networks was studied via an extensive electrospinning test matrix. The summary of the network quality is given in Table 2, and the SEM images of the representative network samples are shown in Figs. 1 and 2.

The concentration of CA in the water and acetone solvent systems has a crucial effect on the spinning process. With an increase of the CA content (beyond $10 \mathrm{wt} \%$ ), very fast evaporation of the solvent occurred, and significant residue of the CA tended to block the needle. This prevented the electrospinning process from taking place in making successful fibers. Lower CA concentrations ranging between 1 and $8 \mathrm{wt} \%$, resulted in very even and high-quality fibers, but they did not allow the receival of continuous fibers with a diameter more than approximately $100 \mathrm{~nm}$. Naturally, a low fiber diameter makes the fiber network difficult to work with in practice. Similarly, Son et al. (2004) reported an optimum CA and water concentration of $10 \mathrm{wt} \%$ and $15 \mathrm{wt} \%$, respectively in their study of electrospun ultrafine CA-acetone-water fibers. Blocking was reported in lower water contents (higher CA).

Table 2. Electrospinning Capability and Fiber Quality of Rosin and Propolis in a Solution Based on Acetone with either $\mathrm{H}_{2} \mathrm{O}$ or DMAc

\begin{tabular}{|c|c|c|}
\hline $\begin{array}{c}\text { Series } \\
(\mathbf{w t} \%)\end{array}$ & Spinnability & $\begin{array}{c}\text { Fiber diameter, } \\
\text { range }(\mathbf{n m})\end{array}$ \\
\hline $\begin{array}{c}\mathrm{CA}(1 \text { to } 20 \%) \\
+\left(\mathrm{H}_{2} \mathrm{O}\right)\end{array}$ & $\begin{array}{c}\text { Solutions with } \mathrm{H}_{2} \mathrm{O} \text { decreases fiber } \\
\text { diameter. }\end{array}$ & 100 to 400 \\
\hline $\begin{array}{c}\mathrm{CA}(5 \text { to } 20 \%) \\
+(\mathrm{DMAc})\end{array}$ & $\begin{array}{c}\text { Increasing } \mathrm{CA} \text { leads to higher fiber } \\
\text { diameter. }\end{array}$ & 100 to 200 \\
\hline $\begin{array}{c}\mathrm{CA}(10 \%)+\text { rosin } \\
+\left(\mathrm{DMAc} / \mathrm{H}_{2} \mathrm{O}\right)\end{array}$ & $\begin{array}{c}\text { Rosin dosage }(1 \text { to } 5 \%) \text { leads to a stable } \\
\text { process yet easily forms beads. }\end{array}$ & $>400$ \\
\hline $\begin{array}{c}\mathrm{CA}(10 \%)+\text { propolis } \\
+\left(\mathrm{DMAc} / \mathrm{H}_{2} \mathrm{O}\right)\end{array}$ & $\begin{array}{c}\text { Propolis dosage }(1 \text { to } 5 \%) \text { leads to a } \\
\text { stable process yet easily forms beads. }\end{array}$ & $>100$ \\
\hline
\end{tabular}


a

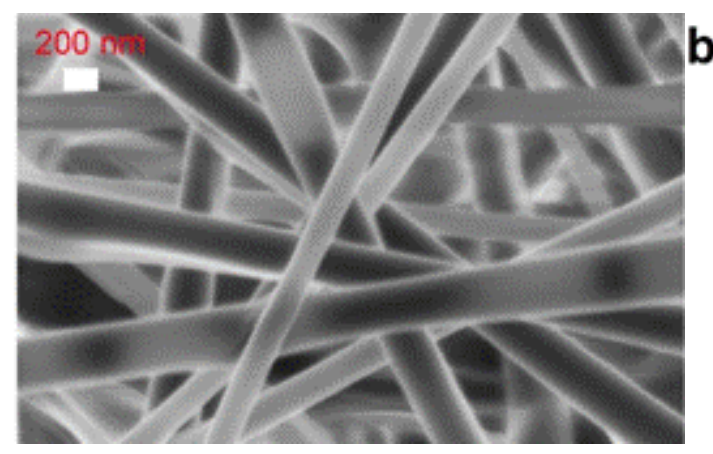

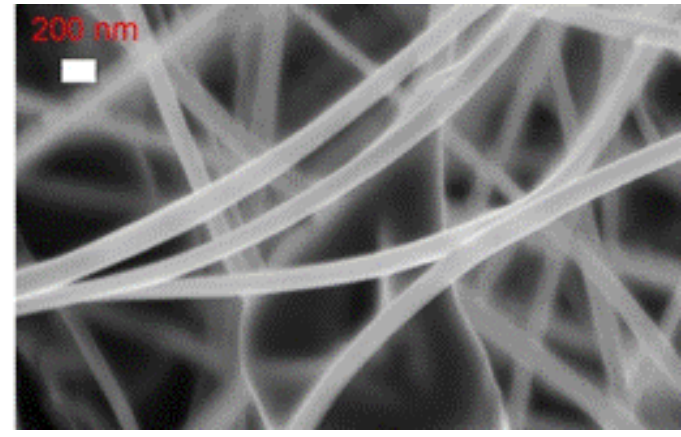

Fig. 1. Electrospun pure CA fiber networks based on either DMAc or $\mathrm{H}_{2} \mathrm{O}$ solution: a) CA (10\%) in $\mathrm{H}_{2} \mathrm{O}$ basis; b) $\mathrm{CA}(5 \%)$ in DMAc basis

a

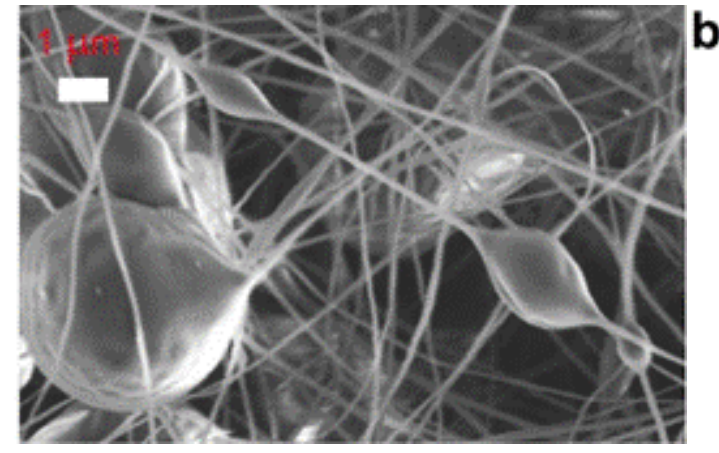

C

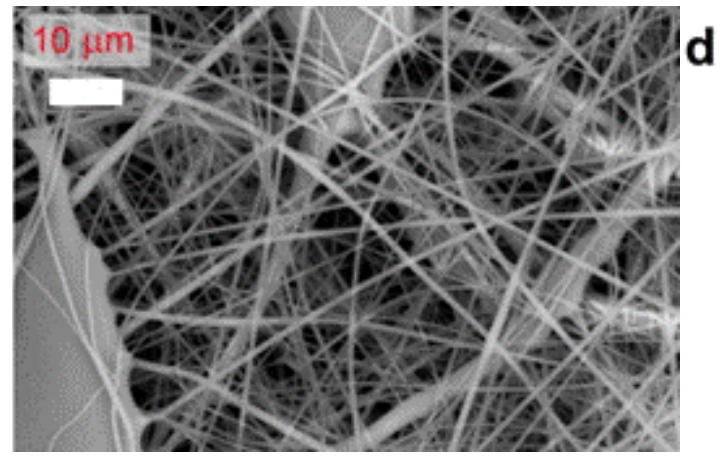

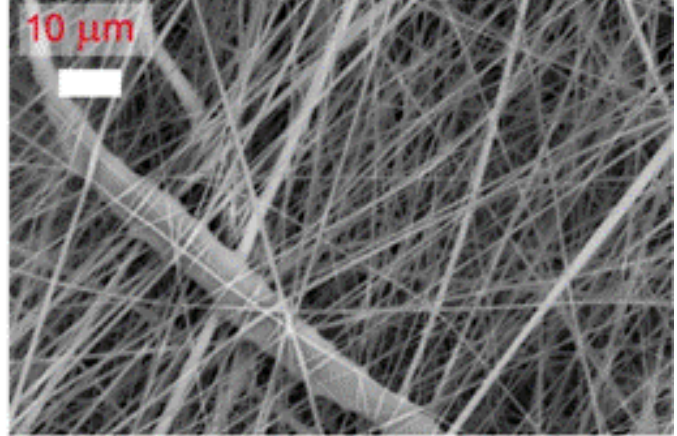

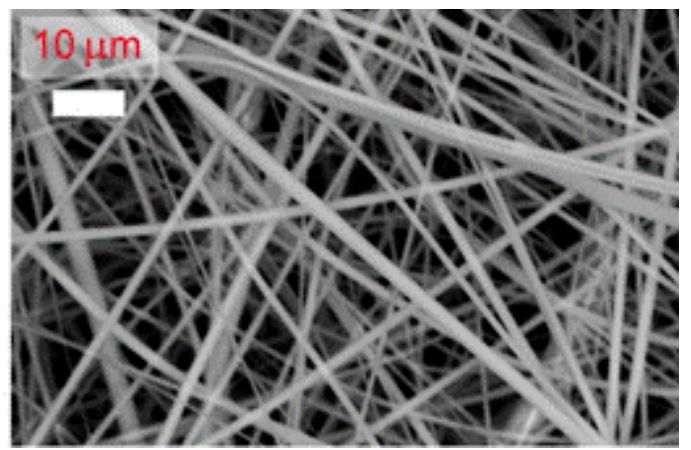

Fig. 2. Electrospun CA fiber networks with various rosin or propolis concentrations: a) CA (10\%) rosin $5 \%$ in DMAc basis; b) CA (10\%) propolis II $5 \%$ in DMAc basis; c) CA (10\%) rosin $1 \%$ in DMAc basis; d) CA (10\%) rosin 5\% in DMAc basis

In general for the DMAc systems, thicker fibers were associated with higher CA concentrations. The spinning process in terms of the flow and even formation of networks was determined to be successful in all the applied CA concentrations. For the highest concentrations (20 wt \%), slight accumulation emerged at the tip of the spinning needle during the electrospinning process. This made it necessary to clean the tip frequently. Luo et al. (2013) found a CA range of 12 to $15 \mathrm{wt} \%$ for their CA-acetone-dimethylformamide (DMF) and Anitha et al. defined a range of 6 to $14 \mathrm{wt} \%$ for CA-acetone-DMF (Anitha et al. 2012). These ranges agree with the CA concentrations of the DMAc systems found in this study.

The rosin and propolis integration (both propolis types) was shown to affect the electrospinning process by making it stabilized and led to a more uniform product. The 
addition of either rosin or propolis allowed for an increase in the processing speed (up to 5 to $7 \mathrm{~mL}$ per h), whereas without these additives, the speed was only 1 to $2 \mathrm{~mL}$ per h (higher rates led to dripping and frequent needle clean up). Along with the higher rates, rosin and propolis made the spinning process more steady, i.e., the jet of the solution was more stable. However, the addition of rosin and propolis tended to lead to the formation of beads in the nanofiber network (see Fig. 3). In agreement with the literature, mixtures with CA and carbon nanotubes (Luo et al. 2013) as well as CA and zinc oxide ( $\mathrm{ZnO}$ ) (Anitha et al. 2012) tend to form aggregates or beads since precipitation or aggregation occurs during spinning. When only rosin is used (in a DMF solution), additives have been reported to improve the quality of electrospun fibers and decrease their diameter (Nirmala et al. 2013). Here, the beads in the CA-rosin systems were studied using AFM and their content tended to be solid and homogenous. The beaded cross sections suggested that pure, phase separated rosin does not form the beads, but the rosin merely hinders the electrospinning process and the solution flow when the formation of beads occurs. The chemical composition and stiffness variation over individual beads inside the networks and fibers is an ongoing challenge. Therefore, it was not surveyed here.

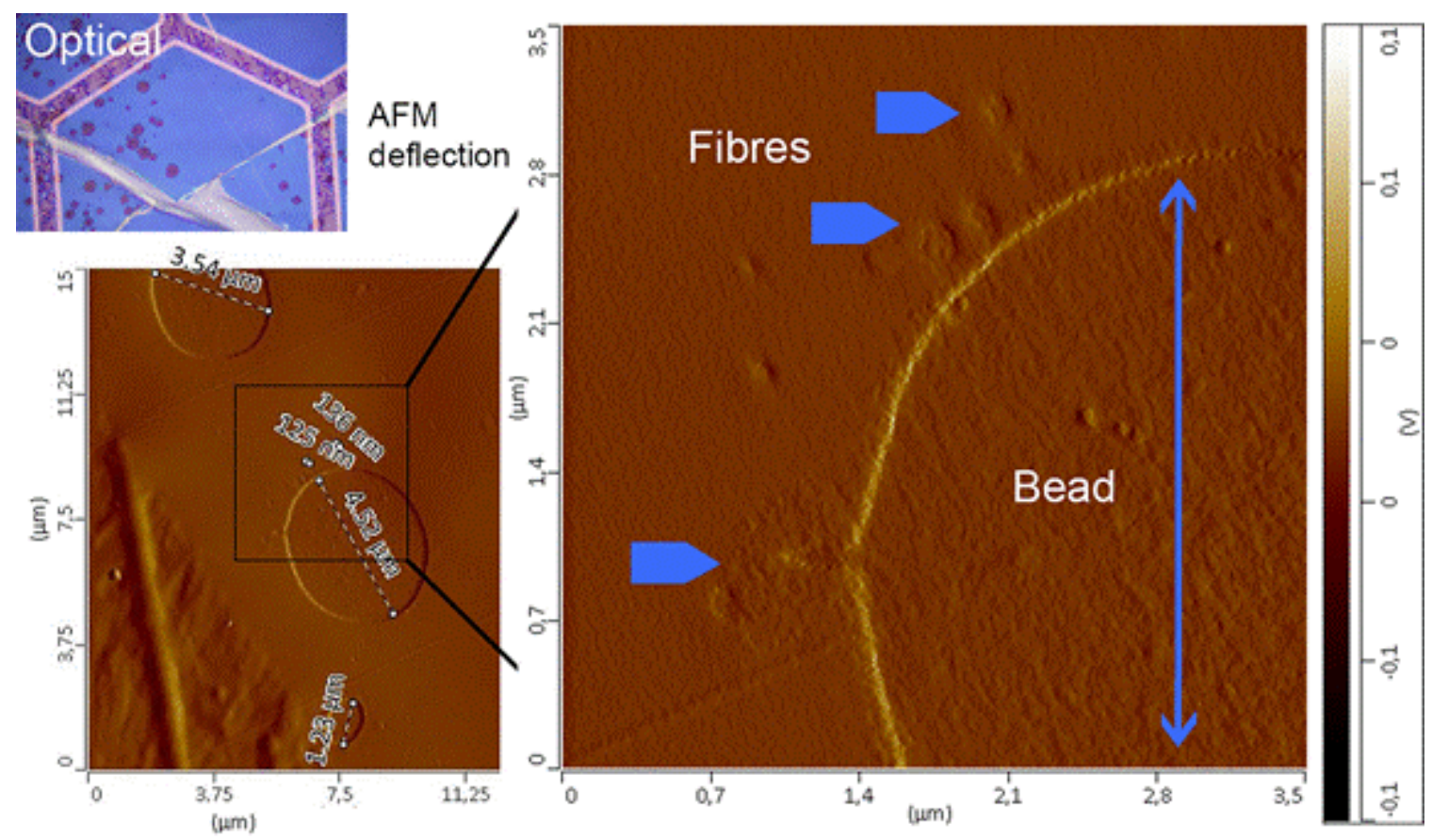

Fig. 3. AFM analysis of the CA-rosin electrospun network and the fiber and beaded cross sections. The measurements were done in contact mode using an Au coated silicon probe. The ultra-microtomed slices including the electrospun network sample were laid on TEM grids with a carbon film.

\section{Chemical Changes by FTIR}

In order to support successful integration of rosin, propolis I, and propolis II into the CA fibers, the FTIR spectra of the pure rosin, pure propolis I, pure propolis II, pure CA fibers, rosin integrated CA fibers, and propolis integrated CA fibers (propolis I and II) were analyzed (Figs. 4 through 5). Figure 4a shows the FTIR spectra of pure rosin, pure propolis I, and pure propolis II, where the rosin spectrum indicates a high content of abietic acid (Matsuyama et al. 2019). 

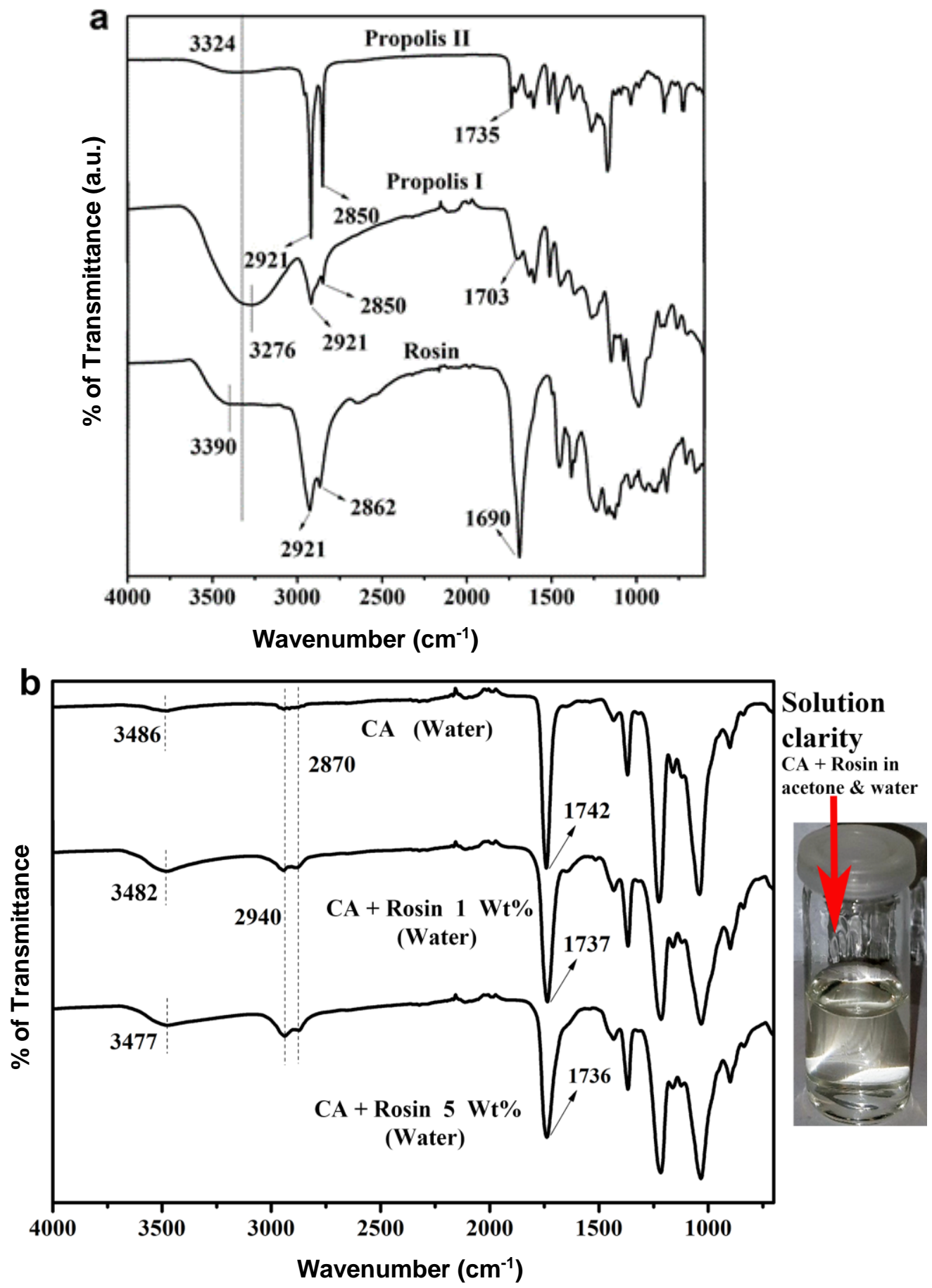

Fig. 4. FTIR spectra of the raw materials used and electrospun CA fibers: a) raw materials; $b$ ) electrospun $\mathrm{CA}$ fibers with rosin $\left(\mathrm{H}_{2} \mathrm{O}\right.$ basis)

First, it was observed that the carboxylic group of rosin showed a characteristic peak for the $>\mathrm{C}=\mathrm{O}$ stretching (Moustafa et al. 2017) vibration band and the $\mathrm{O}-\mathrm{H}$ stretching vibration at $1690 \mathrm{~cm}^{-1}$ and $3390 \mathrm{~cm}^{-1}$, respectively. By contrast, the $>\mathrm{C}=\mathrm{O}$ stretching vibration for propolis I and propolis II were indicated at $1703 \mathrm{~cm}^{-1}$ and $1735 \mathrm{~cm}^{-1}$ and the $\mathrm{O}-\mathrm{H}$ stretching (Hussein et al. 2017) vibration appeared at $3276 \mathrm{~cm}^{-1}$ and $3324 \mathrm{~cm}^{-1}$, respectively. For propolis, the $>\mathrm{C}=\mathrm{O}$ peak was seen rather weak which could indicate the 
presence of hydroxycinnamic acids typical in propolis. For rosin, due to the $\mathrm{C}-\mathrm{H}$ asymmetric stretching vibration of $-\mathrm{CH}_{3}$ group and symmetric $\mathrm{C}-\mathrm{H}$ stretching vibration of $-\mathrm{CH}_{2}$ group, the characteristic bands (Moustafa et al. 2017) appeared at approximately 2921 and $2862 \mathrm{~cm}^{-1}$, respectively. In the data of propolis I and propolis II, the $\mathrm{C}-\mathrm{H}$ asymmetric and symmetric stretching (Hussein et al. 2017) vibration peaks appeared at $2921 \mathrm{~cm}^{-1}$ and $2850 \mathrm{~cm}^{-1}$, respectively

The data in Fig. 4b shows the FTIR spectra of pure CA fibers (water), CA fibers with rosin $1 \mathrm{wt} \%$ of water and CA fibers with rosin $5 \mathrm{wt} \%$ of water. The pure CA fibers (water) clearly show the characteristic peak at $3486 \mathrm{~cm}^{-1}$ for the $\mathrm{O}-\mathrm{H}$ stretching vibration of hydroxyl groups (Fei et al. 2017), whereas this peak in the CA fibers with rosin $1 \mathrm{wt} \%$ of water and CA fibers with rosin $5 \mathrm{wt} \%$ of water appear at $3482 \mathrm{~cm}^{-1}$ and $3477 \mathrm{~cm}^{-1}$, respectively. The CA fibers (water) show a $>\mathrm{C}=\mathrm{O}$ stretching vibration peak at $1742 \mathrm{~cm}^{-1}$ due to the ester group (Fei et al. 2017) of CA. These peaks are shifted to $1737 \mathrm{~cm}^{-1}$ and $1736 \mathrm{~cm}^{-1}$ in CA fibers with rosin $1 \mathrm{wt} \%$ of water and CA fibers with rosin $5 \mathrm{wt} \%$ of water, respectively. The slight shift in the $\mathrm{O}-\mathrm{H}$ and $>\mathrm{C}=\mathrm{O}$ stretching vibration peak in the CA fibers with rosin (water) from the CA fibres (water) is due to the H-bonding interaction between the functional groups of rosin and functional groups of CA. Besides this, CA fibers (water) show a characteristic peak at $2940 \mathrm{~cm}^{-1}$ and $2870 \mathrm{~cm}^{-1}$ due to the $\mathrm{C}-\mathrm{H}$ asymmetric stretching vibration of the $-\mathrm{CH}_{3}$ group and symmetric stretching (Fei et al. 2017) vibration of the $-\mathrm{CH}_{2}$ group of $\mathrm{CA}$.

In rosin-integrated CA fibers (water), these peaks appear more clearly along with a higher intensity due to the merging of the $\mathrm{C}-\mathrm{H}$ stretching of rosin with $\mathrm{CA}$. Figure $5 \mathrm{a}$ shows the FTIR spectra of the CA fibers (water), the CA fibers with propolis I at $4 \mathrm{wt} \%$ and CA fibers with propolis II at $4 \mathrm{wt} \%$. From Fig. 5a, it can be observed that a slight shift occurs in some of the peak positions for propolis I and propolis II integrated CA fibers with respect to the $\mathrm{CA}$ fibers. This can be attributed to the interfacial interaction between $\mathrm{CA}$ with propolis I and propolis II. The $>\mathrm{C}=\mathrm{O}$ stretching vibration peak in both the $\mathrm{CA}$ fibers with propolis I $4 \mathrm{wt} \%$ of water and also CA fibers with propolis II $4 \mathrm{wt} \%$, shifted to $1736 \mathrm{~cm}^{-1}$. However, the $\mathrm{O}-\mathrm{H}$ stretching vibration peak shifted to $3480 \mathrm{~cm}^{-1}$ and $3477 \mathrm{~cm}^{-1}$ in CA fibers with propolis I $4 \mathrm{wt} \%$ of water and CA fibers with propolis II $4 \mathrm{wt} \%$, respectively. This suggests that the H-bonding interaction between propolis II and the CA fibers is slightly stronger compared to propolis I and the CA fibers. Though the pure propolis I and pure propolis II show the $\mathrm{C}-\mathrm{H}$ stretching vibration (asymmetric and symmetric) peak at the same wave number $\left(2921 \mathrm{~cm}^{-1}\right.$ and $\left.2850 \mathrm{~cm}^{-1}\right)$, the propolis I-CA fibers (water) and propolis II-CA fibers (water) show a shift in these peak positions.

The $\mathrm{C}-\mathrm{H}$ asymmetric and symmetric stretching vibration in CA fibers (water) $\left(2940 \mathrm{~cm}^{-1}\right.$ and $2870 \mathrm{~cm}^{-1}$ ) shifted to $2921 \mathrm{~cm}^{-1}$ and $2852 \mathrm{~cm}^{-1}$ in propolis II-CA fibers (water) and $2940 \mathrm{~cm}^{-1}$ and $2880 \mathrm{~cm}^{-1}$ in propolis I-CA fibers (water). These peaks are clearly more intense in propolis I-CA fibers (water) and propolis II-CA fibers (water) compared to the pure $\mathrm{CA}$ fibers (water). This can be attributed to the merging of the $\mathrm{C}-\mathrm{H}$ stretching of propolis I and propolis II with CA fibers. In general, rosin and propolis addition led to single-color and essentially transparent solutions (see an example in Fig. 4b) i.e. fully dissolved systems, and not to dispersions. However, during electrospinning, solvent is being extracted upon fiber formation and certain (nano scale) phase separation could occur. On a nano scale, based on AFM (Fig. 3) imaging, no evident phase separation was observed in the samples. 

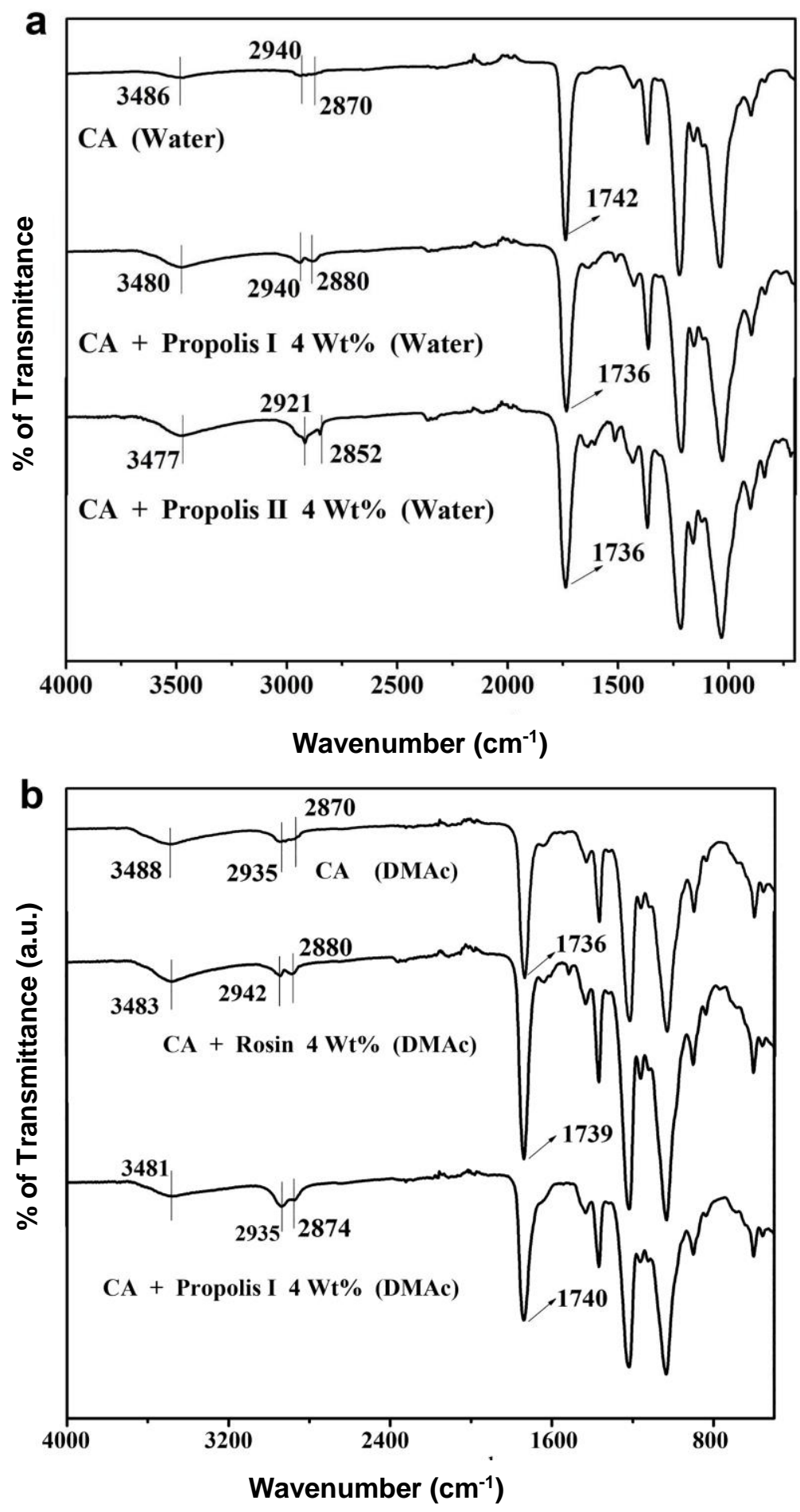

Fig. 5. FTIR spectra of electrospun CA fibers with rosin and propolis contents: a) propolis containing fiber networks $\left(\mathrm{H}_{2} \mathrm{O}\right.$ basis); b) propolis and rosin containing fiber networks (DMAc basis)

\section{Antibacterial Activity}

The antibacterial response was studied for the $\mathrm{H}_{2} \mathrm{O}$ - and the DMAc-based systems. As a control, a CA-network of pure polyethylene (PE) pellets were used. First, the rosin and propolis containing fiber networks with the $\mathrm{H}_{2} \mathrm{O}$ basis were analyzed. The results for 
a typical input of one million bacterial cells showed an antibacterial response only for the rosin containing sample (decrease of approximately one to two logs), as shown in Fig. 6a. When the input was decreased to 20,000 bacteria, almost all the samples indicated strong antibacterial activity. The rosin containing sample resulted in a decrease of two logs in the bacterial count after $24 \mathrm{~h}$. For both propolis samples, the response was dependent on the propolis content (Fig. 6a through b) so that the increase of $3 \mathrm{wt} \%$ in the propolis content resulted in an additional log decrease in the bacterial count.
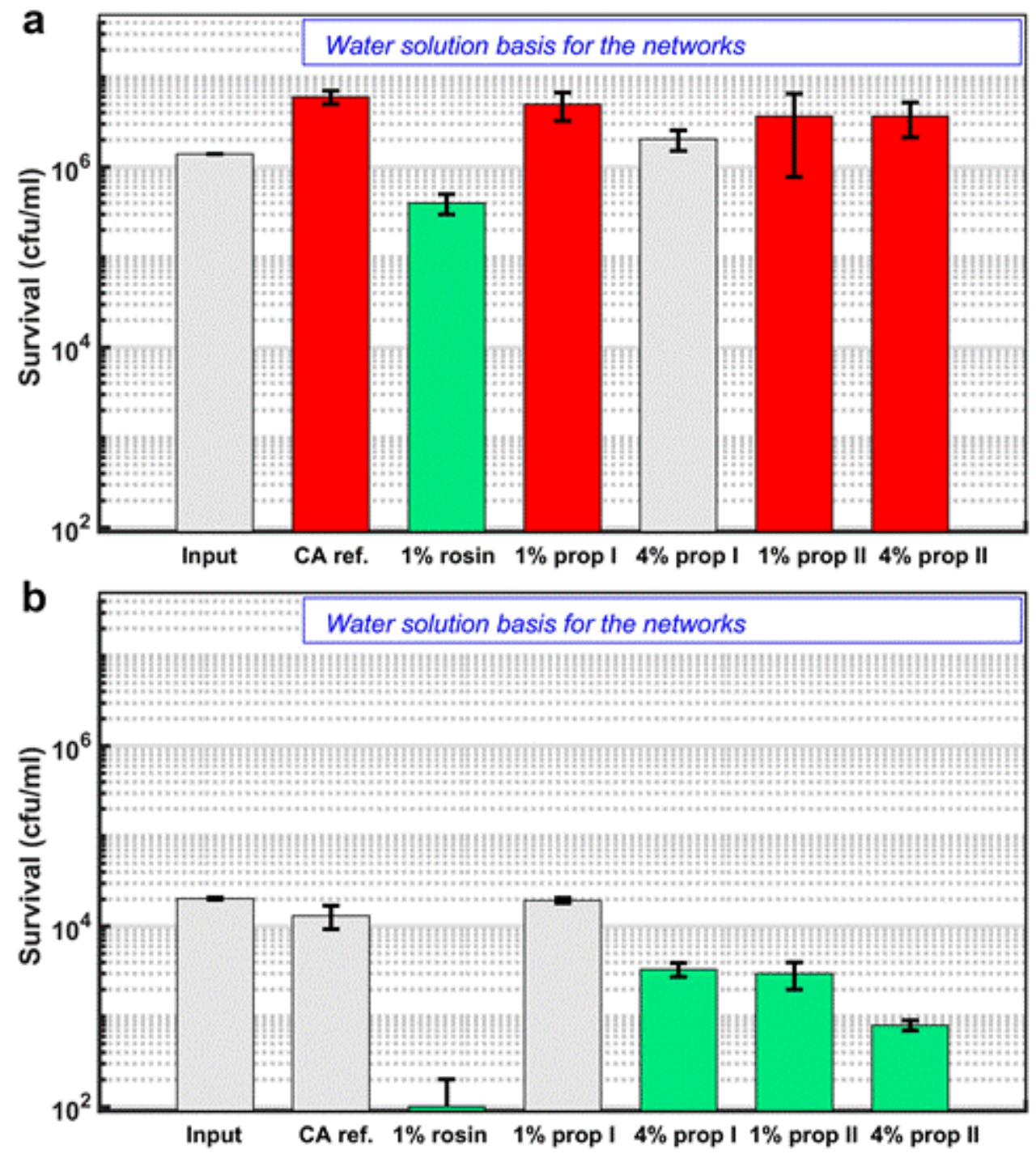

Fig. 6. Antibacterial activity of electrospun fiber networks against $S$. aureus: a) $\mathrm{H}_{2} \mathrm{O}$ solvent systems; b) $\mathrm{H}_{2} \mathrm{O}$ solvent systems for a lower input of bacteria. The analysis was carried out for approximately $1 \mathrm{~cm}$ by $1 \mathrm{~cm}$ samples (approximately 1.3 to $2.5 \mathrm{mg}$ ) in liquid (Ringer's medium, $1 / 4$ strength) and after $24 \mathrm{~h}$ of mixing at room temperature. The analysis resolution is approximately 100 cfu per $\mathrm{mL}$. Pure CA and polyethylene (PE) fibers were used as the reference.

The antibacterial response in general is not unexpected, since the rosins of several wood species have relatively fast $(<24 \mathrm{~h})$ and strong activity against $S$. aureus compared to other wood extracts, and among other bacterial strains (Vainio-Kaila et al. 2017a). However, processing and probable chemical interaction can hinder the effect of rosin in various polymeric systems (Kanerva et al. 2019). The chemical composition of rosin can 
be analyzed in detail. The species responsible for the activity against $S$. aureus have not been completely proven (Vainio-Kaila et al. 2017b). The rosin (abietic) acids are often suggested as the primary reason for the deletion of bacteria based on the effect by pure acids and rosins with various acid contents (Söderberg et al. 1990). The cellulosic molecules are digestible for bacteria making CA a probable counter acting component in the electrospun networks of this study. On the other hand, it has been reported for certain environments that cellulosic extracts can improve viability of probiotic bacteria and this way increase antibacterial effects of the probiotic bacteria (Polari et al. 2012).
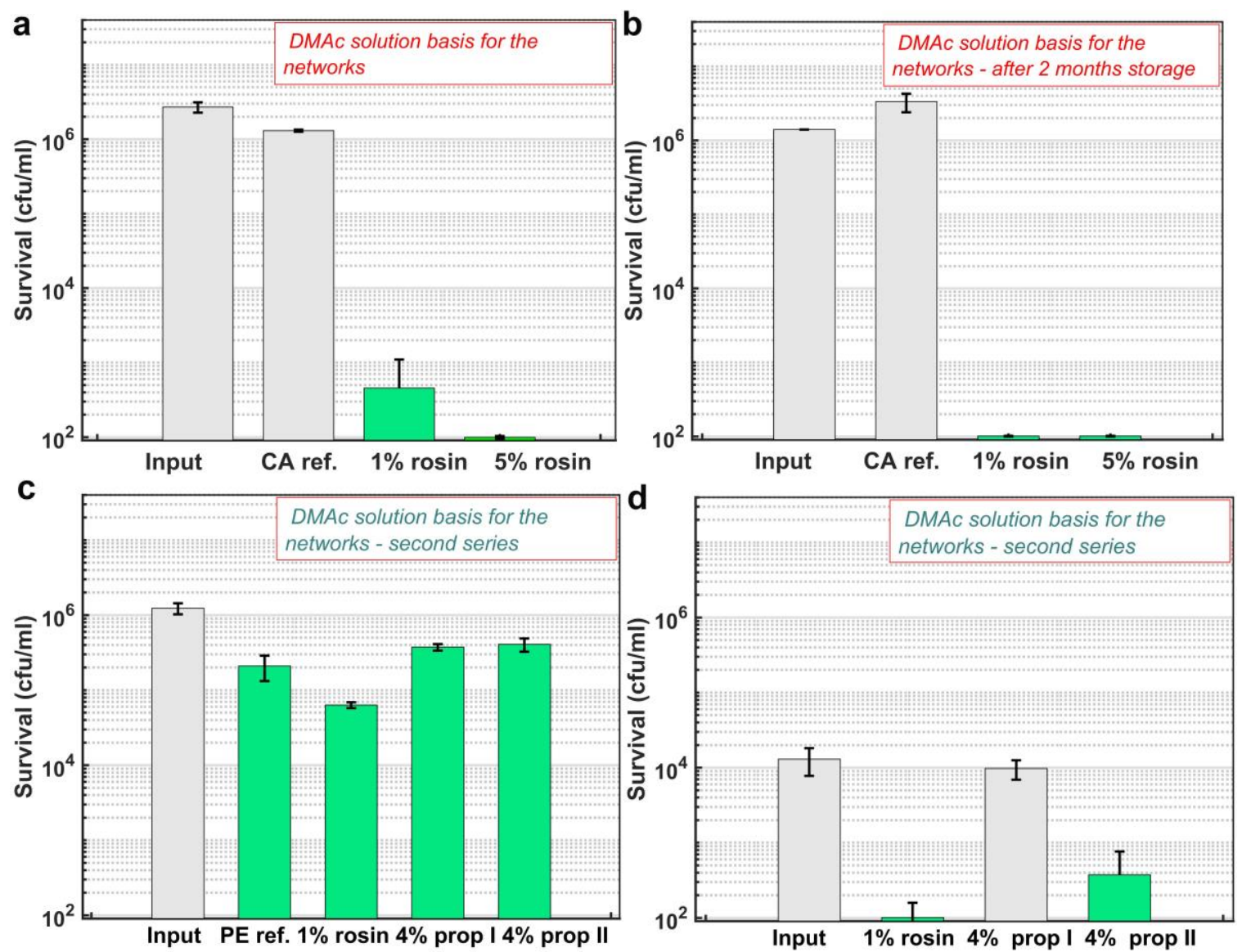

Fig. 7. Antibacterial activity of electrospun fiber networks against $S$. aureus: a) DMAc solvent systems; b) DMAc solvent systems after two months; c) second series DMAc solvent systems; d) second series DMAc solvent systems for a lower input of bacteria. The analysis was carried out for approximately $1 \mathrm{~cm}$ by $1 \mathrm{~cm}$ samples (approximately 1.3 to $2.5 \mathrm{mg}$ ) in liquid (Ringer's medium, $1 / 4$ strength) and after $24 \mathrm{~h}$ of mixing at room temperature. The analysis resolution is 100 cfu per $\mathrm{mL}$. Pure CA and polyethylene (PE) fibers were used as the reference.

Due to the relatively low activity of the propolis- and rosin-containing samples with the water basis, the DMAc systems were studied. As shown in Fig. 7a through b, the DMAc basis resulted in highly antibacterial fiber networks. A rosin content of $5 \mathrm{wt} \%$ led to a minimum $4 \log$ bacterial reduction even with fiber networks stored for two months at room temperature. The results with the DMAc basis were confirmed by a resynthesized (parallel) series, where the antibacterial responses are shown in Fig. 7c and d. The quantitative activity was somewhat lower for the reproduced series, but all the systems were still found to be antibacterial. The rosin-containing samples were the most antibacterial, with over 
$90 \%$ and $99 \%$ killing achieved with $1 \mathrm{wt} \%$ of rosin at an input of about $10^{6}$ and $10^{4}$ bacteria, respectively.

In summary, the antimicrobial effect of rosin and propolis depended on the antimicrobial compound used and its concentration in the fibers. It is important to note that the effects of propolis were propolis-type dependent in this study. Additionally, the effects due to certain extracts such as pollen in propolis, generally vary based on the region of cultivation (Fatrcova-Šramková et al. 2013). Here, rosin was superior over propolis and increasing the concentration of rosin improved the killing action. In addition, the number of bacteria mixed with the test material affected the relative killing effect. The more bacteria used, the less impressive inhibition was seen. This occurred even though the absolute number of dead bacteria was much higher with higher a bacterial input.

Although the quantitatively determined response of fibrous systems with bacterial cells in an aqueous environment is important, antimicrobial analyses of electrospun fibers are often made by agar diffusion. The method is reliable and gives clear visible results, but it is less suitable for very hydrophobic materials such as rosin. Very hydrophobic materials hardly dissolve in water-based agar and thus do not spread properly by diffusion. Consequently, the bacteria are only killed in the proximity of the test spot or disk. In addition, the agar diffusion method makes it difficult to obtain quantitative comparable data of the killing efficiency apart from the inhibition zone diameter, which cannot be translated into bacterial counts. As an example, propolis has been reported to possess a clear response against $E$. coli on the agar surface, but a reliable quantitative comparison from narrow inhibition zones is impossible (Sutjarittangtham et al. 2014). Therefore, instead of using the agar diffusion method, the bacteria were incubated with the fibers in liquid and the bacterial survival was determined by plate counting. By rotating the test tube containing the fibers and bacteria in Ringer's solution, the cells were able to touch the fibers. Therefore, the bacteria had a chance to be killed.

Different antimicrobials have previously been tested in electrospun fiber networks, but any direct comparison to anything other than the rosin-doped antibacterial CA fibers is tricky. Antimicrobials used in electrospun fibers include metals, antibiotics, bacteriocins, and bacteriophages (Mohammadi et al. 2019). Many metals such as copper and silver as well as antibiotics are highly antimicrobial against various bacteria (Son et al. 2006; Unnithan et al. 2014; Ahire et al. 2016). However, these compounds also have clear disadvantages regarding toxicity and increasing antibiotic resistance. Therefore, natural, biodegradable and nontoxic antimicrobial compounds would be more appropriate for most applications. Such substances could be proteins, bacteriophages, or plant-derived components. Nisin, produced by lactic acid bacteria, is a food-grade antimicrobial peptide which has been tested in electrospun materials (Han et al. 2017). Nisin incorporated fibers remained antimicrobial for only about one week, after which nisin was no longer even bacteriostatic. Likewise, bacteriophages lose their activity over time. In the study by Meireles Gouva et al. in 2015, viable phages could not be detected from the CA film after two weeks. In this study presented here, the rosin fibers did not lose their antimicrobial activity even after two months of storage as shown in Fig. 7 b.

\section{Biocompatibility in Film Form}

To have an idea of the proper rosin level in real applications, a preliminary study about the biocompatibility was performed. For assessing the relative effect of rosin in the CA film (water-acetone system, $10 \mathrm{wt} \%$ of CA), control, pure CA, and the CA plus rosin films were used as culture surfaces. The films formed of rosin $(1 \mathrm{wt} \%)$ and CA were tough 
and solid in general. Wells without sample material were used as a control. Because the cultural plates' surface is designed especially for culturing cells, it has (usually) better compatibility than sample polymer films. Nevertheless, the cells being cultivated on polymer materials were shown to have metabolic activity, as shown in Fig. 8. As a main result, the presence of rosin has a significant effect on the number of viable cells. Figure 8 shows the cell proliferation on the surface of materials. The cells have an oblong shape, which is common for this type of cell. A clear difference (32.8\% lower) in the number of cells between CA and the rosin containing (1 wt \%) test samples was observed (Fig. 9) in the MTT assay data. It should be noted that the concentration of rosin in CA presumably affects the cell activity with a nonlinear trend. The investigations of the cytotoxicity effect of pure rosin would be needed to confirm the overall biocompatibility in future works.
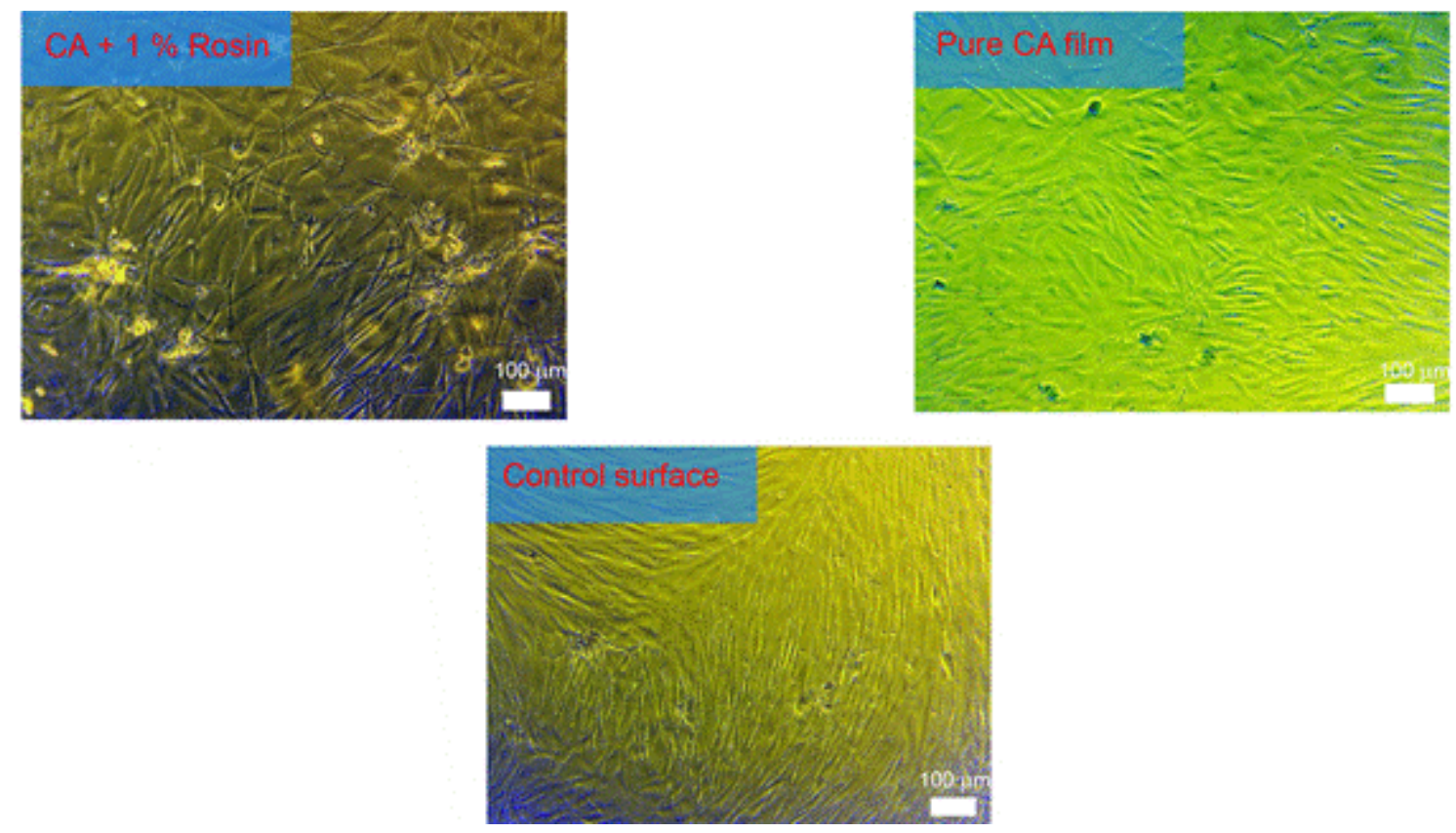

Fig. 8. Results of cultivation of dermal fibroblast cells based on optical microscopy on CA-based films and control surface after four days of cultivation: $1 \mathrm{wt} \%$ rosin content in the CA film, pure CA film, and control surface

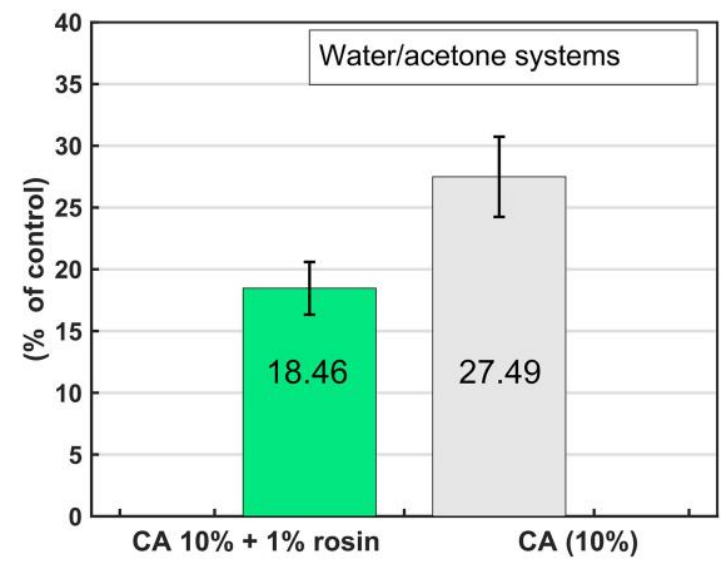

Fig. 9. Presence of dermal fibroblast cells based on optical density by a Nano spectrophotometer on CA-based films and control surface after four days of cultivation: $1 \mathrm{wt} \%$ rosin content in the CA film, pure CA film, and control surface 


\section{CONCLUSIONS}

1. Dimethylacetamide (DMAc) systems with rosin content had the fastest and strongest effect against $S$. aureus (ATCC 12598). Besides, rosin containing cellulose acetate (CA) fiber networks had clearly stronger antibacterial effects when compared to the propolis containing samples.

2. An essentially complete kill (decrease of over four logs in cfu per $\mathrm{mL}$ ) with a rosin concentration of $5 \mathrm{wt} \%$ and an input of 1.2 million bacteria was reached in $24 \mathrm{~h}$ at room temperature.

3. Rosin-CA electrospun fiber networks remain highly antibacterial for at least two months.

4. The electrospinning process was observed to improve by blending rosin and propolis in CA fibers. It also led to consistent fibers at a diameter of 50 to $400 \mathrm{~nm}$. However, it made the fiber spinning sensitive to bead formation with higher concentrations of rosin and propolis.

5. For an input of 20,000 bacteria, the rosin concentration of $1 \mathrm{wt} \%$ is appropriate also for the pure $\mathrm{H}_{2} \mathrm{O}$-acetone solvent systems. Although an observable effect of decreasing the biocompatibility in terms of the viability of dermal fibroblast cells occurs for this rosin concentration of $1 \mathrm{wt} \%$.

\section{ACKNOWLEDGMENTS}

This investigation was funded by a grant from the Business Finland and the participating industry (PIHKA, 1763/31/2016). The authors acknowledge researcher O. Moskaluk for her contribution in the propolis selection. Forchem Oy (Finland) is acknowledged for providing the rosin. The sample preparation in this study made use of the Aalto University Nanomicroscopy Center (Aalto-NMC) premises.

\section{REFERENCES CITED}

Ahire, J., Hattingh, M., Neveling, D., and Dicks, L. (2016). "Copper-containing antibiofilm nanofiber scaffolds as a wound dressing material," PLoS One 11(3), e0152755. DOI: 10.1371/journal.pone.0152755

Anitha, S., Brabu, B., Thiruvadigal, D., Gopalakrishnan, C., and Natarajan, T. (2012). "Optical, bactericidal and water repellent properties of electrospun nano-composite membranes of cellulose acetate and ZnO," Carb. Polym. 87(1), 1065-1072. DOI: 10.1016/j.carbpol.2013.05.003

Asawahame, C., Sutjarittangtham, K., Eitssayeam, S., Tragoolpua, Y., Sirithunyalug, B., and J, S. (2015). "Antibacterial activity and inhibition of adherence of Streptococcus mutans by propolis electrospun fibers," AAPS Pharm. Sci. Tech. 16(1), 182-191.

DOI: 10.1208/s12249-014-0209-5

Awale, S., Li, F., Onozuka, H., Esumi, H., Tezuka, Y., and Kadota, S. (2008).

"Constituents of Brazilian red propolis and their preferential cytotoxic activity against 
human pancreatic PANC-1 cancer cell line in nutrient deprived condition," Bioorg. Med. Chem. Lett. 16, 181-189. DOI: 10.1016/j.bmc.2007.10.004

Barbosa, R., Nunes, T., Nunes, T., Paixao, A., Neto, R., Moura, S., Albuquerque Junior, R., Candido, E., Padilha, F., Quintans-Junior, L., Gomes, M., and Cardoso, J. (2015). "Hydroalcoholic extract of red propolis promotes functional recovery and axon repair after sciatic nerve injury in rats," Pharm. Bio. 1-12, 993-1004. DOI:

10.3109/13880209.2015.1091844

Barrueso-Martínez, M., del Pilar Ferrandiz-Gómez, T., Romero-Sánchez, M., and MartínMartínez, J. (2003). "Characterization of eva-based adhesives containing different amounts of rosin ester or polyterpene tackifier," J. Adhes. 79(8-9), 805-824. DOI: $10.1080 / 00218460309547$

Fei, P., Lia, L., Cheng, B., and Songa, J. (2017). "Quantitative analysis of cellulose acetate with a high degree of substitution by FTIR and its application," Anal. Methods 9(1), 6194. DOI: 10.1039/C7AY02165H

Fatrcova-Šramková, K., Nôžková, J., Kačániová, M., Máriássyová, M., Rovná, K., and Stričik, M. (2013). "Antioxidant and antimicrobial properties of monofloral bee pollen,” J. Envir. Sci. Health Part B 48(2), 133-138. DOI:

10.1080/03601234.2013.727664

Han, D., Sherman, S., Filocamo, S., and Steckl, A. (2017). "Long-term antimicrobial effect of nisin released from electrospun triaxial fiber membranes," Acta Biomaterialia 53, 242-249. DOI: 10.1016/j.actbio.2017.02.029

Hussein, U., Hassan, N., Elhalwagy, M., Zaki, A., Abubakr, H., Venkata, K., Jang, K., and Bishayee, A. (2017). "Ginger and propolis exert neuroprotective effects against monosodium glutamate-induced neurotoxicity in rats," Molecules 22(1), 1982. DOI: 10.3390/molecules22111928

Kanerva, M., Puolakka, A., Takala, T., Elert, A., Mylläri, V., Jönkkäri, I., Sarlin, E., Seitsonen, J., Ruokolainen, J., Saris, P., and Vuorinen, J. (2019). “Antibacterial polymer fibres by rosin compounding and melt-spinning," Mat. Today Comm. 20, 100527. DOI: 10.1016/j.mtcomm.2019.05.003

Kim, J. I., Pant, H. R., Sim, H. J., Lee, K. M., and Kim, C. S. (2014). "Electrospun propolis/polyurethane composite nanofibers for biomedical applications", Mat. Sci. Eng.: C 44, 52-57. DOI: 10.1016/j.msec.2014.07.062

Konwarh, R., Karak, N., and Misra, M. (2013). "Electrospun cellulose acetate nanofibers: The present status and gamut of biotechnological applications," Biotech. Adv. 31(1), 421-437. DOI: 10.1016/j.biotechadv.2013.01.002

Liu, Y., Yao, K., Chen, X., Wang, J., Wang, Z., Ploehn, H., Wang, C., Chu, F., and Tang, C. (2014). "Sustainable thermoplastic elastomers derived from renewable cellulose, rosin and fatty acids," Polym. Chem. 5, 3170-3181. DOI: 10.1039/C3PY01260C

Luo, Y., Wang, S., Shen, M., Qi, R., Fang, Y., Guo, R., Cai, H., Cao, X., Tomas, H., Zhu, M., and Shi, X. (2013). "Carbon nanotube-incorporated multilayered cellulose acetate nanofibers for tissue engineering applications," Carb. Polym. 91(1), 419-427. DOI: 10.1016/j.carbpol.2012.08.069

Matsuyama, S., Kinugasa, S., Tanabe, K., Tamura, T. (2019), Abietic acid IR spectrum, in: SDBSWeb (Spectral Database for Organic Compounds), National institute of advanced industrial science and technology (AIST), Tokyo, Japan. https://sdbs.db.aist.go.jp/sdbs/cgi-bin/cre_index.cgi 
Meireles Gouvâ, D., Santos Mendonça, R., Lopez Soto, M., and Souza Cruz, R. (2015). "Acetate cellulose film with bacteriophages for potential antimicrobial use in food packaging," LWT - Food. Sci. Tech. 63(1), 85-91. DOI: 10.1016/j.lwt.2015.03.014

Mohammadi, M., Rostami, M., Beikzadeh, S., Raeisi, M., Tabibiazar, M., and Yousefi, M. (2019). "Electrospun nanofibers as advanced antibacterial platforms: A review of recent studies," Int. J. Pharm. Sci. Res. 10(2), 463-473. DOI: 10.13040/IJPSR.09758232.10(2).463-73.

Moustafa, H., Kissi, N., Abou-Kandil, A., Abdel-Aziz, M., and Dufresne, A. (2017). "PLA/PBAT bio-nanocomposites with antimicrobial natural rosin for green packaging," ACS Appl. Mater. Inter. 9(1), 20132. DOI: 10.1021/acsami.7b05557

Nirmala, R., Woo-il, B., Navamathavan, R., Kalpana, D., Lee, Y. S., and Kim, H. Y. (2013). "Influence of antimicrobial additives on the formation of rosin nanofibers via electrospinning," Colloids Surf. B 104, 262-267. DOI: 10.1016/j.colsurfb.2012.12.014.

Niu, X., Liu, Y., Song, Y., Han, J., Pan, H., Niu, X., and Liu, Y. (2018). "Rosin modified cellulose nanofiber as a reinforcing and co-antimicrobial agents in polylactic acid /chitosan composite film for food packaging," Carb. Polym. 183, 102-109. DOI: 10.1016/j.carbpol.2017.11.079Get rights and content

Polari, L., Ojansivu, P., Mäkelä, S., Eckerman, C., Holmbom, B., and Salminen, S. (2012). "Galactoglucomannan extracted from spruce (Picea abies) as a carbohydrate source for probiotic bacteria," J. Agri. Food Chem. 60(44), 11037-11043. DOI: 10.1021/jf303741h

Savolainen, T. (2016). Mehiläisten Maailma: Tunne, Hoida, Harrasta [The world of bees: know, care, participate], Tammi, Helsinki, Finland.

Sipponen, A., Jokinen, J., and Lohi, J. (2007). "Resin salve from the Norwegian spruce tree: a 'novel' method for the treatment of chronic wounds," J. Wound Care 16(2), 72-74. DOI: 10.12968/jowc.2007.16.2.26999

Sipponen, A., Peltola, R., Jokinen, J. J., Laitinen, K., Lohi, J., Rautio, M., Männistö, M., Sipponen, P., and Lounatmaa, K. (2009). "Effects of Norway spruce (Picea abies) resin on cell wall and cell membrane of Staphylococcus aureus," Ultra. Path. 33(3), 128-135. DOI: 10.1080/01913120902889138

Sjöström, E. (1993). Wood Chemistry - Fundamentals and Applications ( $2^{\text {nd }}$ Ed.), Academic Press, Cambridge, US.

Söderberg, T., Gref, R., Holm, S., Elmros, T., and Hallmans, G. (1990). "Antibacterial activity of rosin and resin acids in vitro," Scand. J. Plastic \& Recon. Surg. \& Hand Surg. 24(3), 199-205. DOI: 10.3109/02844319009041279

Son, W., Lee, T., and Park, W. (2004). "Electrospinning of ultrafine cellulose acetate fibre: studies of a new solvent system and deacetylation of ultrafine cellulose acetate fibers," J. Polym. Sci.: Part B Polym. Phys. 42(1), 5-11. DOI: 10.1002/polb. 10668

Son, W., Youk, J., and Park, W. (2006). "Antimicrobial cellulose acetate nanofibers containing silver nanoparticles," Carb. Polym. 65(1), 430-434. DOI: 10.1016/j.carbpol.2006.01.037

Sutjarittangtham, K., Sanpa, S., Tunkasiri, T., Chantawannakul, P., Intatha, U., and Eitssayeam, S. (2014). "Bactericidal effects of propolis/polylactic acid (PLA) nanofibres obtained via electrospinning," J. Apicult. Res. 53(1), 109-115. DOI: 10.3896/IBRA.1.53.1.11 
Toreti, V., Sato, H., Pastore, G., and Park, Y. K. (2013). "Recent progress of propolis for its biological and chemical compositions and its botanical origin," Evid. Based Compl. Alter. Med. 2013, 697390. DOI: 10.1155/2013/697390

Unnithan, A., Gnanasekaran, G., Sathishkumar, Y., Lee, Y., and Kim, C. (2014). "Electrospun antibacterial polyurethane cellulose acetatezein composite mats for wound dressing," Carb. Polym. 102, 884-892. DOI: 10.1016/j.carbpol.2013.10.070

Vainio-Kaila, T., Hänninen, T., and Kyyhkynen, A. (2017a). "Effect of volatile organic compounds from Pinus sylvestris and Picea abies on Staphylococcus aureus, Escherichia coli, Streptococcus pneumoniae and Salmonella enterica serovar Typhimurium,” Holz. 71, 905-912. DOI: 10.1515/hf-2017-0007

Vainio-Kaila, T., Zhang, X., Hänninen, T., Kyyhkynen, A., Johansson, L. S., Willför, Österberg, M., Siitonen, A., and Rautkari, L. (2017b). "Antibacterial effects of wood structural components and extractives from Pinus sylvestris and Picea abies on Methicillin-resistant Staphylococcus aureus and Escherichia coli O157:H7," BioResources 12(4), 7601-7614. DOI: 10.15376/biores.12.4.7601-7614

Varga, J., Brenner, D.A., and Phan, S. (2005). "Fibrosis Research: Methods and Protocols," in: Methods in Molecular Medicine, Humana Press Inc., Totowa, NJ, USA, pp. 392.

Article submitted: November 20, 2019; Peer review completed: January 27, 2020; Revised version received: February 8, 2020; Accepted: March 22, 2020; Published: April 3, 2020. DOI: 10.15376/biores. 15.2.3756-3773 